\title{
Early Recurrent Otitis Media, Language and Central Auditory Processing in Children
}

\author{
Nicci Campbell, René Hugo and Isabel Uys \\ Department of Communication Pathology \\ University of Pretoria \\ Johan Hanekom \\ Department of Electrical and Electronic Engineering \\ University of Pretoria \\ Solly Millard \\ Department of Statistics \\ University of Pretoria
}

\begin{abstract}
The study examines the relationships that exist between early recurrent otitis media, language and central auditory processing in children. A retrospective case-control experimental design was employed and ten subjects were allocated to each of the two research groups, namely children with a history of early recurrent otitis media (research group 1) and children without a history of early recurrent otitis media (research group 2). The children in both research groups were in grade one and turning 7 years old. The language and central auditory processing of the subjects were assessed using the Clinical Evaluation of Language Function (Wiig \& Semel, 1980) and the Willeford Battery of Central Auditory Function (Willeford, 1974). The results showed that the language and central auditory processing of the children with a history of early recurrent otitis media were significantly poorer than that of their disease-free peers. The results stress the importance of vigorous identification and management programmes for children with a history of early recurrent otitis media.
\end{abstract}

\section{OPSOMMING}

Hierdie studie bestudeer die verhoudings wat bestaan tussen vroeë herhaalde otitis media, taal en sentrale ouditiewe prosessering in kinders. ' $n$ Terugkykende geval-beheer eksperimentele navorsingsontwerp is gebruik en tien proefpersone is toegesê aan elkeen van die twee navorsingsgroepe, naamlik kinders met 'n geskiedenis van vroeë herhaalde otitis media (navorsingsgroep 1) en kinders sonder 'n geskiedenis van vroeë herhaalde otitis media (navorsings-groep 2). Die kinders in beide navorsingsgroepe was in graad een en sou sewe jaar oud word. Die taal en sentrale ouditiewe prosessering van die proefpersone is geëvalueer met behulp van die "Clinical Evaluation of Language Function" (Wiig \& Semel, 1980) en die "Willeford Battery of Central Auditory Function" (Willeford, 1974). Die resultate toon dat die taal en sentrale ouditiewe prosessering van die kinders met 'n geskiedenis van vroeë herhaalde otitis media betekenisvol swakker was as vir die kinders sonder ' $n$ geskiedenis van vroeë herhaalde otitis media. Die resultate beklemtoon die belangrikheid van kragtige identifiserings- en behandelingsprogramme vir kinders met' $n$ geskiedenis van vroeë herhaalde otitis media.

KEY WORDS: early recurrent otitis media, language and central auditory processing.

Otitis media, an inflammation of the middle-ear which may or may not be infectious in origin, is one of the most prevalent diseases in childhood (Friel-Patti, 1990). The degree of the conductive hearing loss associated with otitis media is variable, ranging from less than $10 \mathrm{dBHL}$ to as much as 50dBHL (Friel-Patti, 1990; Gravel \& Ellis, 1995). Otitis media usually affects both ears and may be continuous, causing a constant reduced level of hearing or it may be recurrent, causing a fluctuating hearing loss (Northern \& Downs, 1984; Gravel \& Ellis, 1995). The child with a history of early recurrent otitis media or the otitis prone child was first described by Howie, Ploussard and Sloyer (1975) as having six or more episodes of otitis media before six years of age.

Although otitis media has been a recognised concern for health-care professionals, the short- and long-term consequences of early recurrent otitis media and the accompanying, usually temporary, hearing loss for child development are less well understood (Friel-Patti, 1990; Roush \& Henderson, 1995). Children with a history of early re- 
current otitis media are reportedly seen more often than their peers by the speech-language pathologist and audiologist for language and central auditory processing disorders (Collazo \& Kricos, 1986; Paden, 1994). Shriberg \& Kwiatowski (1982, cited in Friel-Patti, 1990) have estimated that one-third of children seen by the speech-language pathologist and audiologist have a history of early recurrent otitis media. A review of the literature does however, yield mixed support for associations between early recurrent otitis media and language disorders in children. Although there is strong support in the literature for associations between early recurrent otitis media and central auditory processing disorders, this evidence is largely based on the results of animal studies (Tees, 1967; Clopton \& Silverman, 1978; Webster, 1983) and a limited number of human studies (Folsom, Weber \& Thompson, 1983; Finitzo, Gunnarson \& Clark, 1990; Hurley \& Hurley, 1995).

Central to the relationships that exist between early recurrent otitis media and language disorders, and early recurrent otitis media and central auditory processing disorders, is the hypothesis of a critical period for language acquisition and the development of the central auditory nervous system. The essential prediction from the critical period hypothesis is that the timing of any adverse experience (such as the fluctuating hearing loss associated with early recurrent otitis media) will be crucial and that after a certain age, the ability to acquire language and central auditory processing skills diminishes so that any deficits remaining at the end of this period are unlikely to be overcome (Mogford \& Bishop, 1988; Gravel \& Ellis, 1995). The notion of a critical period for language acquisition was first proposed by Penfield (1965). Although there is consensus in the literature that the critical period for language acquisition starts at birth, the upper limit of this period remains controversial (Mogford \& Bishop, 1988). Lenneberg (1967) estimates the upper limit at puberty while Krashen (1973, cited in Mogford \& Bishop, 1988) estimates the upper limit at five years of age. The upper limit of the critical period for the development of central auditory nervous system is also controversial and estimates vary from two years of age (Northern \& Downs, 1984) to approximately twelve years of age (Welsh, Welsh \& Healy, 1983; Keith, 1988). The upper limits of the critical period for language acquisition and the development of the central auditory nervous system are thus poorly understood at this time (Mogford \& Bishop, 1988).

Firstly, with regard to the influence of early recurrent otitis media on language development, there are a large number of studies describing the influence of early recurrent otitis media on language acquisition. One of the earliest and most publicized studies describing the negative impact which early recurrent otitis media has on language development in children was documented by Holm and Kunze (1969). Since this study, research findings have reported general delays in speech and language development (Zinkus, Gottlieb \& Schapiro, 1978; Jerger, Jerger, Alford \& Abrams, 1983); lower performance on áuditory perceptual and language processing tests (Zinkus et al., 1978; Brandes \& Ehinger, 1981; Eimas \& Clarkson, 1986); a higher incidence of academic problems, especially reading and spelling disorders; lower scores on tests of phoneme production in connected speech as well as the use of combinations of phonemes in word endings (Needleman, 1977); and a higher frequency of enrolment in special support classes in schools (Brandes \& Ehinger, 1981) as well as in speech and language therapy programmes (Collazo \& Kricos, 1986).

There are, however, studies that have yielded mixed support for associations between early recurrent otitis media and language disorders in children. Owrid (1970) found that children with a history of otitis media (but whose hearing was normal at the time of testing) suffer minor, if any, deficit in terms of vocabulary, language comprehension, syntax and reading level. Roberts, Sanyal, Burchinal, Collier, Ramey and Henderson (1986) found no significant correlations between early recurrent otitis media and outcome measures of standardized test scores for both verbal and non-verbal intelligence and academic functioning. In 1988, in a second study with the same group of children (as used in the study of Roberts et al., 1986) which included speech measures of phonological process analysis and articulation testing, no significant relationship was found between early recurrent otitis media and the number of consonants in error or the number of phonological procésses used (Roberts, Burchinal, Koch, Footo \& Henderson, 1988). However, Feagans, Sanyal, Henderson, Collier and Applebaum (1987) again using the same sample as Roberts et al. (1986), found a correlation between early recurrent otitis media and narrative ability, but no relationship for early recurrent otitis media and mean length of utterance.

The extent to which early recurrent otitis media can be held responsible for impaired language development in children thus remains an unresolved issue. The above opposing positions to the relationship between early recurrent otitis media and language development can possibly be attributed to the differences and limitations in the research methodologies employed in the above studies (Paden, 1994). Firstly, the subject sample is often too small to permit generalizations. Secondly, definitions of the otitis prone condition vary. Thirdly, the age at which the subjects were assessed vary and the subject sample is often too small to permit generalizations. Fourthly, most of the studies concentrated on one area of speech or language but left others unexplored and finally, other variables such as mental retardation, hearing acuity, exposure to more than one language, history of neurological dysfunction and social-domestic problems which may influence measures of language are not always accounted for (Mogford \& Bishop, 1988; Paden, 1994). Further research, which considers the above criticisms, is thus necessary to determine the impact, if any, which early recurrent otitis media has on language acquisition in children.

Secondly, with regard to the influence of early recurrent otitis media on central auditory processing, evidence from animal studies (Tees, 1967; Clopton \& Silverman, 1978; Webster, 1983) has been used to show that periods of auditory deprivation, occurring during a time when the maturational processes of the central auditory pathways are not complete, may result in abnormal development of these pathways. This evidence has taken the form of small but demonstrable neuro-anatomic differences in the brainstem, abnormalities in the higher brainstem electrophysiologic responses (Clopton \& Silverman, 1978), differences in auditory electrophysiologic studies on binaural interaction tasks, and differences in the behavioural responses to complex sound (Tees, 1967).

By way of analogy with animal studies, it has been suggested that auditory deprivation (including the fluctuat- 
ing hearing loss associated with early recurrent otitis media) may have a negative influence on the central auditory nervous system in humans (Downs, 1988). There are, however, disadvantages in the application of the results of animal studies to the developing human auditory system: Firstly, the description of a critical period during which the neural system demonstrates plasticity cannot be directly transferred to human development and secondly, the animals used in the above experiments were operatively given constant conductive hearing impairments during specified periods of time and inferences made with respect to the effects of the fluctuating hearing loss associated with early recurrent otitis media are thus speculative.

The limited number of human studies available provide strong evidence to support a correlation between early recurrent otitis media and central auditory processing disorders in children. Folsom et al. (1983) found significantly greater absolute wave III and V latencies, and I to III and III to V interpeak latencies for children with a history of early recurrent otitis media which suggest subtle differences in brainstem transmission. These findings are consistent with those of Finitzo et al. (1990) who also found differences in the middle latency response of children with a history of early recurrent otitis media. The results of the above studies thus provide evidence for associations between early recurrent otitis media and central auditory processing disorders at brainstem and cortical level.

In an interesting and relevant study reported by Welsh et al. (1983), a group of 35 children with a history of otitis media were assessed using the Willeford Battery of Central Auditory Function (Willeford, 1974). This battery of tests consists of two cortical procedures (the Competing sentence test and the Filtered speech test) and two brainstem procedures (the Binaural fusion test and the Rapidly alternating speech perception test). The results showed that 75 percent of the subjects failed one or more of the four tests. The performance of the subjects was also found to be significantly lower for the Competing sentence test, the Filtered speech test and the Binaural fusion test than for the Rapidly alternating speech perception test. The results of Welsh et al.'s (1983) study thus provide evidence for associations between early recurrent otitis media and central auditory processing disorders at brainstem and cortical level and are consistent with the findings of Folsom et al. (1983) and Finitzo et al. (1990). A critisism that can be directed at the study of Welsh et al. (1983) is that "the child with a history of otitis media" is not clearly defined.

More recently, Hurley and Hurley (1995) have investigated the effect of otitis media on brainstem electrophysiology using matched experimental and control groups. At the time of the testing all the subjects were free of otitis media and had a discernible auditory brainstem response to clicks at $25 \mathrm{dBHL}$. The results showed that the absolute wave III and V latencies of the experimental group were significantly longer than those of the control group. In addition, the I to V interpeak latency of the experimental group was significantly delayed in comparison to the control group.

Despite strong evidence in the literature for associations between early recurrent otitis media and central auditory processing disorders at brainstem and cortical level, further research is necessary to substantiate the results of the limited number of human studies available.
The rationale underlying the study is to examine the relationships that exist between early recurrent otitis media and language and early recurrent otitis media and central auditory processing in children. The results of the study will help the speech-language pathologist and audiologist to determine whether children with a history of early recurrent otitis media are a greater risk for developing language and central auditory processing disorders than their peers.

\section{METHODOLOGY}

\section{AIMS OF THE STUDY}

The main aim of the study is to investigate the influence of early recurrent otitis media on language development and central auditory processing in children. This aim is realized in the following sub-aims:

1. To assess the language and compare the intergroup tendencies of the language of each research group of subjects, namely children with a history of early recurrent otitis media (research group 1) and children without a history of otitis media (research group 2).

2. To assess the central auditory processing and compare the intergroup tendencies of the central auditory processing of each research group of subjects.

\section{RESEARCH DESIGN}

A retrospective case-control experimental design (Roberts \& Schuele, 1990) was employed to observe whether patterns and relationships exist between early recurrent otitis media and language impairment, and early recurrent otitis media and central auditory processing disorders in children.

\section{SUBJECTS}

Seventy-two questionnaires were distributed to five English medium primary schools in Pretoria. The five primary schools that participated in the study, were selected as there was already an established relationship between the staff at these schools and the staff at the Department of Communication Pathology at the University of Pretoria. This Department provides a community service programme that entails screening the hearing and middle-ear functioning of children at these schools on an annual basis. The advantage of using these schools was that greater cooperation could be expected from the staff and thus the parents (all the questionnaires distributed were completed and returned).

The information used to identify possible candidates was obtained from the questionnaires completed by the parents of the children, the school records and personnel declaration. The subject selection criteria included in the study are in accordance with Paden's (1944) recommendation that variables such as age, scholastic level, sex, socio-economic status, intelligence and hearing be controlled when researching the influence of early recurrent otitis media on child development. Possible candidates were required to be in grade one (and turning 7 years old). Children in grade one (and turning 7 years old) were selected to fascilitate the identification of children with and without a history of early recurrent otitis media in accord- 
ance with Howie et al.'s (1975) definition of the "otitis prone" child namely as having six or more episodes of otitis media by 6 years of age. Furthermore, possible candidates were required to use English as their home language and medium of formal education, to have average to aboveaverage cognitive abilities, to have no history of neurological dysfunction or symptoms, to have a middle to higher socio-economic background, to have no emotional or social-domestic problems, and finally to have normal hearing (air-conduction thresholds between 0 and $15 \mathrm{dBHL}$ for the frequency range $125-8000 \mathrm{~Hz}$ ) and normal middle-ear functioning (type A tympanograms with a middle-ear pressure of between -100 and $+50 \mathrm{daPa}$, and a static compliance of between 0,3 and $1,75 \mathrm{~cm}^{3}$ ). The normative data used to interpret the above audiometric test results is based on the norms recommended by Northern \& Downs (1984) and Keith (1988). The subject selection criteria and parameters are presented in Table 1.

Sixteen possible candidates were identified for research group 1 (children with a history of early recurrent otitis media) and twenty-nine possible candidates were identified for research group 2 (children without a history of early recurrent otitis media). Possible candidates for research group 1 were also required to satisfy Howie et al.'s (1975) definition of the "otitis prone" child. 'Twenty sub. jects were then selected using the table of random num. bers method (Roberts \& Schuele, 1990), and ten subjects were allocated to each research group with an even distri. bution of five males and five females per group.

\section{APPARATUS AND MATERIAL}

\section{- Apparatus and material used to identify possible subjects}

\section{- Questionnaire}

A questionnaire was developed to identify children who met the subject selection criteria and thus possible candidates for the study. The areas covered in the questionnaire included the child's name and age, home language, history of otitis media and medical history.

Table 1: Subject selection criteria and parameters

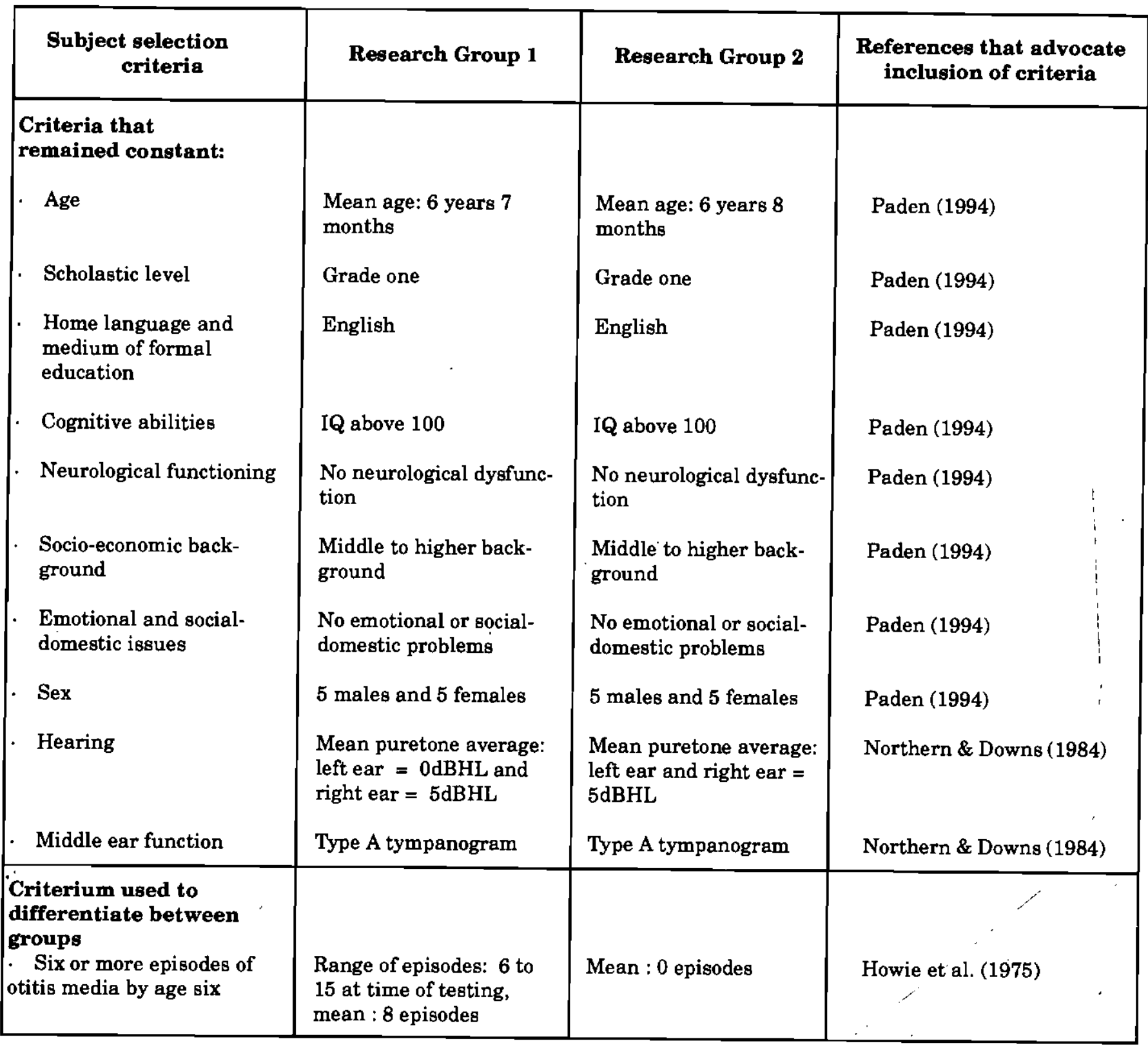




\section{- Audiometric equipment}

A GSI-10 Audiometer and GSI-33 Middle Ear Analyzer were used to assess hearing acuity and middle-ear functioning prior to the assessments of language and central auditory processing. A sound-proof testing booth and Telephonic TDH-50 earphones with MX 41/AR cushions were used. The audiometer and middle-ear analyser were calibrated according to the SAB 0154 - 1979 requirements.

\section{- Apparatus and material used in the evaluation of study groups 1 and 2}

\section{- The Clinical Evaluation of Language Function (Wiig \& Semel, 1980)}

The CELF was selected as this language assessment procedure provides differential measures of selected language functions in the area of phonology, syntax, semantics, memory, word-finding and retrieval. These measures have thus been designed to probe specific areas of language processing and production abilities as well as the ability to process and produce speech sounds in school-age children. A summary of the CELF subtests is provided in Appendix A. All the subtests of the CELF were administered with the exception of the Word series subtest. The Word series subtest was not administered as Wiig and Semel (1980) stipulate (in their test manual) that this subtest should not be administered to children younger than 8 years of age.

A drawback to the choice of the CELF for assessing the language of the subjects in the study is the fact that the CELF has been compiled and standardized for children living in the United States of America (USA) and not children living in the Republic of South Africa (RSA). There is, however, no equivalent measure of language ability with norms available for the RSA population. It is of concern to note that most of the diagnostic measures used in the RSA for research and clinical diagnosis have been obtained from other countries, and the norms are thus not neces. sarily representative of the RSA population. Furthermore, certain words and language structures are specific to different countries and may thus not be familiar to other groups. Although the language structures included in the CELF should be familiar to the RSA population, there are a few words such as "sneakers?", "candy" and "drugstore" that do not form part of South-African English. As the aim of the study was to assess the language and compare the intergroup tendencies of each experimental group (and not the applicability of the CELF norms to the RSA population) it was decided to use the CELF without any adaptations or changes to the test items but to familiarize the subjects with the unfamiliar words prior to the testing (by explaining the meanings of the words and asking the subjects to repeat the words). A list of the words with which the subjects were familiarized is presented in Appendix B.

- The Willeford Battery of Central Auditory Function (Willeford, 1974)

The Willeford Battery of Central Auditory Function was selected as this battery of tests provides normative data for children from the age of five years and consists of four separate procedures for assessing central auditory processing. Two of the procedures have been designed to assess cortical function and two to assess the integrity of the brainstem. The cortical procedures are the Competing sentence test and the Filtered speech test. The brainstem measures are the Binaural fusion test and the Rapidly alternating speech perception test. The Willeford Battery of Central Auditory Function (Willeford, 1974) was purchased from Professor J A Willeford and consists of an audio-cassette with the test stimuli, a test manual and normative data. A summary of the tests of the Willeford Battery of Central Auditory Function is provided in Appendix $\mathrm{C}$.

The drawbacks to the choice of the Willeford Battery of Central Auditory Function for assessing the central auditory processing of the subjects in the study are firstly, that this battery of tests has been compiled and standardized for the USA and not the RSA population, and secondly, the audio-casette with the test stimuli has been recorded using the voice of an adult male speaker with a USA accent.

Although the language structures used in the Willeford Battery of Central Auditory Function should be familiar to the RSA population, there are a few words and phrases such as "gas", "dime" and "Fourth of July" that do not form part of South-African English. As the aim of the study was to assess the central auditory processing and compare the intergroup tendencies of each experimental group (and not the applicability of the norms of the Willeford Battery of Central Auditory Function to the RSA population) it was decided to use this battery of tests without any adaptations or changes to the test items but to familiarize the subjects with the unfamiliar words and phrases prior to the testing (by explaining the meaning of the words and phrases, and asking the subjects to repeat the words). A list of the words with which the subjects were familiarized is presented in Appendix D.

The test stimuli of the Willeford Battery of Central Auditory Function were retaped, using the voice of a speaker with a South African accent as the impact of the unfamiliar accent would have influenced not only a few but all the test items. Permission to retape the test stimuli was obtained from Professor J A Willeford (personal telephone conversation, 1989). An electrical engineer at the Department of Electrical and Electronical Engineering at the University of Pretoria built the filters and equipment required to retape the test stimuli (as stipulated in the test manual) and the test stimuli were recorded using the voice of an adult male speaker with a South-African accent similar to that of the subjects.

\section{- Audiometric equipment}

A GSI-10 Audiometer and Philips N2520 audio-cassette recorder were used for administering the Willeford Battery of Central Auditory Function to the subjects. The testing took place in a sound-proof booth and Telephonic TDH-50 earphones with MX41/AR cushions were used.

\section{DATA COLLECTION PROCEDURES}

The twenty subjects were individually assessed at the Department of Communication Pathology at the University of Pretoria. Each subject was exposed to a 2 hour 20 minute test procedure and the testing was completed in a single session. Subjects were, however, permitted to rest if they became fatigued, and all the subjects were given a break of 15 minutes and refreshments midway through the testing.

Puretone testing and immittance were administered using the instructions and procedures stipulated by ANSI 
53.21 - 1978 (in Silman \& Silverman, 1991) and the GSI33 Middle Ear Analyzer test manual. Subjects were required to have normal hearing acuity and middle-ear functioning as a prerequisite to the administration of the CELF and the Willeford Battery of Central Auditory Function. The average time required to complete the puretone testing and immittance was 10 minutes per subject.

The subjects were then familiarized with the words listed in Appendixes B and D prior to the administration of the CELF and Willeford Battery of Central Auditory Function. The meaning of the words in these appendixes were explained and the subjects were asked to repeat the words. This process took approximately 10 minutes per subject.

The CELF was then administered in a quiet nondistractable room following the standardized instruction and administration procedures stipulated in the CELF Diagnostic Examiners manual. The average time required for the administration of the CELF was 1 hour 10 minutes per subject.

Finally, the Willeford Battery of Central Auditory Function was administered following the standardized instructions and procedures stipulated in the test manual. The average time that was required for the administration of this battery of tests was $\mathbf{5 0}$ minutes.

\section{DATA ANALYSIS AND PROCESSING}

The subtests and tests of the CELF and Willeford Battery of Central Auditory Function were totalled for each subject by adding the scores obtained for each item. This information was then analyzed by a statistician using an IBM 370 Computer and the Biomedical Computer Programme. The statistical procedures' employed to achieve each sub-aim are presented in Table 2.

\section{RESULTS AND DISCUSSION}

This section is presented according to the formulated sub-aims and entails a description and comparison of the language and central auditory processing of research groups 1 and 2.

\section{DESCRIPTION AND COMPARISON OF THE LANGUAGE PERFORMANCE OF RESEARCH GROUPS 1 AND 2}

The first sub-aim (namely, to determine and compare the intergroup tendencies of the language of research groups 1 and 2) was realized by administering the CELF (Wiig \& Semel, 1980) to the subjects in the two research groups. The General linear models procedure (Steyn, Smit \& du Toit, 1989) was used to establish the arithmetic mean of each research group for each subtest of the CELF, and the Signed-rank test (with a 5\% level of significance) was used to determine whether significant differences occurred between the language performance of research groups 1 and 2 (Steyn et al., 1989). These results are presented in Table 3.

The language processing subtests on which research group 1 exhibited significantly lower scores than that of research group 2 (at the $5 \%$ level of significance) were the Word and sentence structure subtest (which assesses the ability to process and interpret word and sentence structures), the Linguistic concepts subtest (which evaluates the ability to process and interpret oral directions which contain linguistic concepts requiring logical operations), the Relationships and ambiguities subtest (which assesses the ability to process and interpret logico-grammatical and ambiguous sentences) and the Oral directions subtest (which evaluates the ability to interpret, recall and execute oral commands of increasing length and complexity). These results thus support the research findings of Zinkus et al. (1978), Brandes and Ehinger (1981), and Eimas and Clarkson (1986) who reported that children with a history of otitis media have significantly poorer receptive language abilities and have difficulty understanding complex and/or lengthy language structures.

The language processing subtests on which no significant differences occurred (at the $5 \%$ level of signifi-

Table 2: The statistical procedures used to achieve each sub-aim

\begin{tabular}{|c|c|}
\hline Sub-Aim & Statistical Procedures \\
\hline $\begin{array}{l}\text { 1. To determine the level of language performance and } \\
\text { compare the intergroup tendencies of the language per- } \\
\text { formance of research groups } 1 \text { and } 2\end{array}$ & $\begin{array}{l}\text { The General linear models procedure was used } \\
\text { to establish the arithmetic mean of each research group } \\
\text { for each subtest of the CELF (Steyn, Smit \& du Toit, 1989) } \\
1.2 \text { The Signed-rank test (with a 5\% level of sig- } \\
\text { nificance) was used to determine whether significant } \\
\text { differences occurred between the language performance } \\
\text { of research groups } 1 \text { and } 2 \text { (Steyn et al., 1989) }\end{array}$ \\
\hline $\begin{array}{l}\text { 2. To determine the level of central auditory processing } \\
\text { and compare the intergroup tendencies of the central au- } \\
\text { ditory processing of research groups } 1 \text { and } 2\end{array}$ & $\begin{array}{l}2.1 \text { The General linear models procedure was used } \\
\text { to establish the arithmetic mean of each research group } \\
\text { for each test of the Willeford Battery of Central Auditory } \\
\text { Function (Steyn et al., 1989) } \\
2.2 \text { The Signed-rank test (with a 5\% level of sig- } \\
\text { nificance) was used to determine whether significant } \\
\text { differences occurred between the central auditory process- } \\
\text { ing of research groups } 1 \text { and } 2 \text { (Steyn et al., 1989) }\end{array}$ \\
\hline
\end{tabular}


cance) in the performance of research groups 1 and 2 were the Word classes subtest (which evaluates the ability to perceive relationships between verbal concepts and identify word pairs) and the Spoken paragraphs subtest (which evaluates the ability to process and interpret salient information presented). The Word classes subtest consists of items featuring three or four verbal concepts of which two are associated. The child is required to identify the two concepts which are related. The subjects in both research groups 1 and 2 found this subtest less taxing than the other language processing subtests, and it is thus possible that the Word classes subtest is less sensitive than the other language processing subtests in identifying the language impair-ment associated with early recurrent otitis media in children. The Spoken paragraphs subtest consists of four paragraphs of increasing length and complexity and the child is required to recall details such as proper names, numerical and geographical data. The subjects in both research groups 1 and 2 performed poorly on this subtest and can possibly be attributed to the high incidence of unfamiliar words (that do not form part of South-
African English, for example: candy, drugstore and dollar) which occur in this subtest. The subjects in both research groups had difficulty in recalling these words despite having been familiarized with these words prior to the testing. This finding highlights the need for language assessment procedures that have been compiled and standardized for the RSA population.

The language production subtests on which research group 1 exhibited significantly lower scores than that of research group 2 (at the $5 \%$ level of significance) were the Confrontation naming subtest (which evaluates the child's accurancy, fluency and speed in naming colours, forms, and colour-form combinations), the Model sentences subtest (which assesses productive control of sentence structures in a sentence repetition task) and the Formulated sentence subtest (which evaluates the ability to formulate and produce sentences). These results support the research findings of Jerger et al. (1983) and Menyuk (1986) who found that children with a history of otitis media produce fewer sentences with prepositional phrases, use a higher incidence of simple sentences and experience difficulties with

Table 3: A comparison of the language performance of research groups 1 and 2 on the Celf subtests (at the 5\% level of significance)

\begin{tabular}{|c|c|c|c|c|c|}
\hline \multirow{2}{*}{\multicolumn{3}{|c|}{ The Celf Subtest }} & \multicolumn{2}{|c|}{$\begin{array}{c}\text { Average achievements or } \\
\text { arithmetic means of research } \\
\text { groups } 1 \text { and } 2\end{array}$} & \multirow{2}{*}{$\begin{array}{l}\text { Comparison of the } \\
\text { language performance } \\
\text { of research groups } 1\end{array}$} \\
\hline & & & $\begin{array}{c}\text { Research } \\
\text { group } 1\end{array}$ & $\begin{array}{c}\text { Research } \\
\text { group } 2\end{array}$ & \\
\hline \multirow[b]{6}{*}{ 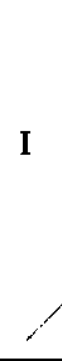 } & 1 & Word and sentence structure & 20 & 25 & \\
\hline & 2 & Word classes & 10,7 & 11,3 & \\
\hline & 3 & Linguistic concepts & 26 & 28,7 & \\
\hline & 4 & Relationships and ambiguities & 9,9 & 19,7 & \\
\hline & 5 & Oral directions & 11 & 15,6 & \\
\hline & 6 & Spoken paragraphs & 1 & 1,1 & \\
\hline \multirow{5}{*}{ II } & 7 & Confrontation naming: accuracy & 29,1 & 32,7 & \\
\hline & & Confrontation naming: time & 161,8 & 130 & \\
\hline & 8 & Word associations & 11 & 11 & \\
\hline & 9 & Model sentences & 19 & 23 & \\
\hline & 10 & Formulated sentences & 14 & 16 & \\
\hline \multirow{4}{*}{ III } & 11 & Processing speech sounds & 119,8 & 120 & \\
\hline & 12 & Producing speech sounds - blends & 52 & 52 & \\
\hline & & Producing speech sounds - final position & 18 & 18 & \\
\hline & & Producing speech sounds - initial position & 20 & 20 & \\
\hline
\end{tabular}

KEY:

I Language processing subtests

II Language production subtests

III Supplementary subtests

$\square$ No significant difference between research groups 1 and 2 .

Performance of research group 1 lower than experimental group 2. 
syntax and morphological markers.

There was, however, no difference in the performance of research groups 1 and 2 for one of the language production subtests, namely the Word associations subtest (which evaluates the quantity and quality of the retrieval of semantically related word series from long term memory). This subtest requires the child to name as many members as possible from two semantic classes, foods and animals, in sixty seconds. The subjects in both research groups 1 and 2 found this subtest less taxing than the other language production subtests, and it is thus possible that the Word associations subtest is less sensitive than the other language production subtests in identifying the language impairment associated with early recurrent otitis media in children.

There were also no significant differences between the two research groups (at the 5\% level of significance) for the supplementary subtests of the CELF, namely the Processing of speech sounds subtest (which evaluates the ability to discriminate between speech sounds in minimally different word pairs) and the Producing speech sounds subtest (which evaluates the child's accuracy in articulating blends, final position phonemes and initial position phonemes). These results support the research finds of Roberts et al. (1988) who found no significant correlations between early recurrent otitis media, auditory discrimination and articulation disorders in children.

\section{DESCRIPTION AND COMPARISON OF THE CEN- TRAL AUDITORY PROCESSING OF RESEARCH GROUPS 1 AND 2}

The second sub-aim (namely, to determine and compare the intergroup tendencies of the central auditory processing of research groups 1 and 2) was realized by adminis- tering the Willeford Battery of Central Auditory Function (Willeford, 1974) to the subjects in the two research groups. The General linear models procedure (Steyn et al., 1989) was used to establish the arithmetic mean of each research group for each test of the Willeford Battery of Central Auditory Function, and the Signed-rank test (with a 5\% level of significance) was used to determine whether significant differences occurred in the central auditory processing of research groups 1 and 2 (Steyn et al., 1989). These results are presented in Table 4.

The results of the Willeford Battery of Central Auditory Function showed that the central auditory processing of subjects in research group 1 was significantly lower than that of research group 2 for both of the cortical procedures, namely the Filtered speech test (test conditions: left and right ear) and the Competing sentence test for the weak ear condition. These results support the research findings of Welsh et al. (1983) who reported that children with a history of otitis media exhibit lower scores than their disease-free peers on the cortical procedures of the Willeford Battery of Central Auditory Function.

There was, however, no significant difference between the two research groups for the strong ear condition of the Competing sentence test. This finding suggests that the maturation of the strong ear condition may be less susceptible to the negative influence of early recurrent otitis media. Further research is, however, necessary to substantiate this hypothesis as there is no evidence in the literature to support this finding. It is interesting to note that the strong ear was the right ear for all the subjects in research groups 1 and 2 . As documented in Kaplan, Gladstone \& Katz (1984), the strong ear is usually the right ear and scores in the weak ear continue to improve until the age of ten years when ear performance becomes equal for the competing sentence test.

Table 4: A comparison of the central auditory processing of research groups 1 and 2 (at the $5 \%$ level of significance)

\begin{tabular}{|c|c|c|c|c|c|}
\hline & The Willeford & & $\begin{array}{r}\text { Average } \\
\text { arithmeti } \\
\text { rese }\end{array}$ & $\begin{array}{l}\text { vement or } \\
\text { ans of each } \\
\text { group }\end{array}$ & $\begin{array}{l}\text { Comparison of the } \\
\text { central auditory }\end{array}$ \\
\hline & & & $\begin{array}{l}\text { Research } \\
\text { group } 1\end{array}$ & $\begin{array}{c}\text { Research } \\
\text { group } 2\end{array}$ & groups 1 and 2 \\
\hline 1 & Competing sentence test & *Weak ear & 30 & 67 & \\
\hline & & *Strong ear & 85 & 89 & \\
\hline 2 & Filtered speech test & Left ear & 21 & 46 & \\
\hline & & Right ear & 20 & 51 & \\
\hline 3 & Binaural fusion test & Left ear & 80 & 87 & \\
\hline & & Right ear & 81 & 88 & \\
\hline 4 & Rapidly alternating speach & Left ear & 75 & 90 & \\
\hline$\therefore$ & perception test & Right ear & 77 & 92 & \\
\hline
\end{tabular}

KEY:

No significant difference between research groups 1 and 2.

Performance of experimental group 1 lower than research group 2.

* The weak ear was the left ear and the strong ear the right ear for all the subjects in research groups 1 and 2 
The performance of research group 1 was also significantly lower than that of research group 2 for the first brainstem procedure, namely the Rapidly alternating speech perception test (test conditions : left and right ear performance) but no significant difference occurred for the second brainstem procedure, namely the Binaural fusion test (test conditions : left and right ear performance). These results contradict the research findings of Welsh et al. (1983) who reported that children with a history of otitis media exhibit lower scores than their disease-free peers on the Binaural fusion test but similar scores for the Rapidly alternating speech perception test. These contradictions can possibly be attributed to the fact that the subjects included in the study were familiarized with the words listed in Appendix D. prior to the testing (as discussed in the Methodology). This procedure may have influenced the internal validity of the Binaural fusion test (where the child is asked to repeat words filtered in such a way that a low pass segment is presented to one ear and a high pass segment is simultaneously presented to the other ear) as it is easier to remember and repeat words with which one is familiar. The Rapidly alternating speech perception test consists of sentences which are presented in alternating bursts of $300 \mathrm{~m}$. sec. duration to first the one ear and then the other. Although the subjects were familiarized with the unfamiliar words included in these sentences, they were not familiarized with the actual sentences which are more difficult to repeat than words (as required for the Binaural fusion test).

The above results thus provide evidence for associations between early recurrent otitis media and delayed central auditory processing abilities and support the research finds of the limited number of human studies (Folsom et al., 1983; Welsh et al., 1983; Finitzo et al., 1990; Hurley \& Hurley, 1995) available.

To summarize, the results of the study found the language and central auditory processing abilities of children with early recurrent otitis media to be significantly poorer than that of their disease-free peers. This finding is concerning as the children included in the study were in grade one (and turning seven years old). Children with a history of early recurrent otitis media thus enter school at a disadvantage as impaired and/or delayed language and central auditory processing abilities place children at greater risk for developing scholastic difficulties (FrielPatti, 1990). The language and central auditory processing impairments and/or delays associated with early recurrent otitis media should thus ideally be resolved before children enter school (Paden; 1994). Although the results do not shed much light on the hypothesis of a critical period, it would appear that early recurrent otitis media has a negative influence on the development of language and central auditory processing during the first six years of life. Further research is necessary to determine the barriers of the critical period and to determine whether children are able to overcome language and central auditory processing disorders once the upper limit of this period has been reached.

A criticism that can be directed at the study and other retrospective studies (Holm \& Kunze, 1969; Zinkus et al., 1978; Collazo \& Kricos, 1986) is the fact that parental recall and physician's records of children's histories of early recurrent otitis media are not always accurate (Paden, 1994). Based on the results of the study, it is felt that a prospective longitudinal study where the history of otitis media is carefully monitored and documented, and language and central auditory processing are assessed from birth to puberty would help to improve the speech-language pathologist and audiologist's understanding of the associations that exist between early recurrent otitis media, language and central auditory processing in children. Prospective research is, however, expensive and is thus not always practical or viable, particularly in a country such as the Republic of South Africa where the poor economic situation has resulted in drastic financial cutbacks in research programmes. It is hoped that the results of the study will help to stress the importance of further research in this area, and that a prospective study will be possible in the near future. In the interim, the results of the study stress the importance of vigorous prevention, identification and intervention programmes for children with a history of early recurrent otitis media.

\section{CONCLUSION}

The results of the study have shown that the language and central auditory processing of the children with a history of early recurrent otitis media (research group 1) were significantly poorer than for their disease-free peers (research group 2). Children with a history of early recurrent otitis media were thus found to enter school at a disadvantage as impaired and/or delayed language and central auditory processing abilities place children at greater risk for developing scholastic difficulties. The results of the study stress the importance of vigorous prevention, identification and intervention programmes for children with a history of early recurrent otitis media and the need for further research to improve the speech-language pathologist and audiologist's understanding of the relationships that exist between early recurrent otitis media, language and central auditory processing in children.

\section{REFERENCES}

Brandes, P.J. \& Ehinger, D.M. (1981). The effects of early middle ear pathology on auditory perception and academic achievement. Journal of Speech and Hearing Disorders, 46, 301-307.

Clopton, B.M. \& Silverman, M.S. (1978), Changes in latency and duration of neural responses following developmental auditory deprivation. Experimental Brain Research, 32, 3947.

Collazo, M. \& Kricos, P. (1986). Otitis prone children and the need for speech/language services. Hearing instruments, $37,14-19$.

Downs, M.P. (1988). Contribution of Mild Hearing Loss to Auditory Language

Learning Problems. In Roeser, R.J. \& Downs, M.P. (Eds.): Auditory Disorders in School Children. New York: Thieme Medical Publishers, Inc.

Eimas, P.D. \& Clarkson, R.L. (1986). Speech perception in children: are there effects of otitis media? In Kanagh, J.F. (Ed.): Otitis media and child development. Parkton: York Press.

Feagans, L., Sanyal, M., Henderson, F., Collier, A. \& Applebaum, M. (1987).

Relationship of middle ear disease in early childhood to later narrative and attention skills. Journal of Paediatric Psychology, 12, 581-594.

Finitzo, T., Gunnarson, A.D. \& Clark, J.L. (1990). Auditory deprivation and early conductive hearing loss from otitis media. Topics in Language Disorders, 11 (1), 29-42.

Folsom, R.C., Weber, B.A. \& Thompson, G. (1983). Auditory brainstem response measures in children with early recurrent middle-ear disease. Annals of Otolaryngology, Rhinology and Laryngology, 92, 249-253. 
Friel-Patti, S. (1990). Otitis media with effusion and the development of language: A review of evidence. Topics in Language Disorders, 11 (11), 11-22.

Gravel, J.S. \& Ellis, M.A. (1995). The auditory consequences of otitis media with effusion: the audiogram and beyond. Seminars in Hearing, 16(1), 44-59.

Holm, V.A. \& Kunze, R.H. (1969). The effects of chronic otitis media on language and speech development. Paediatrics, 43, 833-841.

Howie, V.M., Ploussard, J.H. \& Sloyer, J. (1975). The 'otitis prone' condition. American Journal of Diseases in Children, 129, 676-678.

Hurley, R.M. \& Hurley, A. (1995). The auditory brainstem response in children with histories of otitis media. Seminars in Hearing, 16(1), 37-43.

Jerger, S.J., Jerger, J., Alford, B.R. \& Abrams, S. (1983). Development of speech intelligibility in children with recurrent otitis media. Ear and hearing, 4, 138-145.

Kaplan, H., Gladstone, V.S. \& Katz, J. (1984). Site of Lesion Testing - Audiometric Interpretation, Volume II. Baltimore: University Park Press.

Keith, R.W. (1988). Central Auditory Tests. In Lass, N.J., Reynolds, L.V.,

Northern, T.L. \& Yoder, D.E. (Eds,): Handbook of SpeechLanguage Pathology and Audiology. Toronto: B.C. Decker, Inc.

Lenneberg, E.H. (1967). The Biological Foundations of Language. New York: Wiley.

Menyuk, R. (1986). Predicting speech and language problems with persistent otitis media. In Kawanagh, J.F. (Ed.): Otitis media and child develop-ment. Parkton: York Press.

Mogford, K. \& Bishop, D. (1988). Five questions about language acquisition considered in the light of exceptional circumstances. In Bishop, D. \& Mogford, $K$. (Eds): Language development in exceptional circumstances. Edinburgh: Churchill Livingstone.

Needleman, H. (1977). Effects of hearing loss from early recurrent otitis media on speech and language development. In Jaffe, B.F. (Ed.): Hearing Loss in Children. Baltimore: University Park Press.

Northern, J.L. \& Downs, M.P. (1984). Hearing in Children. Baltimore: The Williams and Co.

Owrid, H.L. (1970). Hearing impairment and verbal attainment in primary school children. Educational Research, 12, 209214.
Paden, E.P. (1994). Otitis media and disordered phonologies: some concerns and cautions. Topics in Language Disorders, 14(2), 72-83.

Penfield, W. (1965). Conditioning the uncommitted cortex for language learning. Brain, 88, 787-798.

Roberts, J.E., Burchinal, M., Koch, M., Footo, M. \& Henderson, F. (1988). Otitis media in early childhood and its relationship to later phonological development. Journal of Speech and Hearing Disorders, 53, 416-424.

Roberts, J.E., Sanyal, M.A., Burchinal, M.R., Collier, A.M., Ramey, C.T. \& Henderson, F.W. (1986). Otitis media in early childhood and its relationship to later verbal and academic performance. Paediatrics, 78, 428-430.

Roberts, J.E. \& Schuele, C.M. (1990). Otitis media and later academic performance. The linkage and implications for intervention. Topics in Language Disorders, 11(1), 43-62.

Roush, J. \& Henderson, F. (1995). Medical and audiological management of otitis media: consensus and controversy. Seminars in Hearing, 16(1), 105-112.

Silman, S. \& Silverman, C.A. (1991). Auditory diagnosis: Principles and Applications. San Diego: Academic Press, Inc.

Steyn, A.G.W., Smit, C.F. \& du Toit. (1989). Moderne Statistiek vir die Praktyk. Pretoria: J.L. van Schaik, Ltd.

Tees, R.C. (1967). The effects of early auditory restrictions in the rat on adult auditory discrimination. Journal of Auditory Research, 7, 195-207.

Webster, D.B. (1983). Acritical period during post-natal auditory development of mice. International Journal of Paediatric Otorhinolaryngology, 6, 107-118.

Welsh, L.W., Welsh, J.J. \& Healy, M.P. (1983). Effects of sound deprivation on central hearing. Laryngoscope, 93 (12), 1569 1576.

Wig, E.H. \& Semel, E.M. (1980). Clinical Evaluation of Language Function. Columbus, Ohio: Charles, E. Merrill Publishing Company.

Willeford, J.A. (1974). Willeford Battery of Central Auditory Function. Colorado: Department of Audiology, Colorado State University.

Willeford, J.A. (1989). Personal Telephone Conversation. Department of Audiology, Colorado State University.

Zinkus, P.W., Gottlieb, M.I. \& Schapiro, M. (1978). Developmental and psycho-educational sequelae of chronic otitis media. American Journal of Disabilities in Children, 132, 1100-1104. 
Appendix A: Summarized overview of the subtest of the celf (Wiig \& Semel, 1980)

\begin{tabular}{|c|c|c|c|}
\hline \multirow{7}{*}{ I } & & Subtest & Description of each subtest \\
\hline & 1 & Word and sentence structure & $\begin{array}{l}\text { Assesses the child's ability to process and interpret selected word and sen- } \\
\text { tence structures. }\end{array}$ \\
\hline & 2 & Word classes & $\begin{array}{l}\text { Evaluates the child's ability to perceive relationships between verbal con- } \\
\text { cepts and identify word pairs. }\end{array}$ \\
\hline & 3 & Linguistic concepts & $\begin{array}{l}\text { Evaluates the ability to process and interpret oral directions which contain } \\
\text { linguistic concepts requiring logical operations. }\end{array}$ \\
\hline & 4 & Relationships and ambiguities & $\begin{array}{l}\text { Evaluates the ability to process and interpret logico-grammatical and am- } \\
\text { biguous sentences. }\end{array}$ \\
\hline & 5 & Oral directions & $\begin{array}{l}\text { Evaluates the ability to interpret, recall and execute oral commands of in- } \\
\text { creasing length and complexity. }\end{array}$ \\
\hline & 6 & Spoken paragraphs & $\begin{array}{l}\text { Evaluates the ability to process and interpret spoken paragraphs and recall } \\
\text { salient information presented. }\end{array}$ \\
\hline \multirow{5}{*}{ II } & 7 & Word series & $\begin{array}{l}\text { Assesses the accuracy, fluency and speed in recalling and producing selected } \\
\text { automatic-sequential word series. }\end{array}$ \\
\hline & 8 & Confrontation naming & $\begin{array}{l}\text { Evaluates the accuracy, fluency, and speed in naming colours, forms, and } \\
\text { colour-form combinations in a sustained confrontation-naming task. }\end{array}$ \\
\hline & 9 & Word associations & $\begin{array}{l}\text { Evaluates the quantity and quality of the retrieval of semantically related } \\
\text { word series from long term memory. }\end{array}$ \\
\hline & 10 & Model sentences & $\begin{array}{l}\text { Assesses productive control of sentence structure in a sentence repetition } \\
\text { task. }\end{array}$ \\
\hline & 11 & Formulated sentences & $\begin{array}{l}\text { Evaluates the ability to formulate and produce sentences when word and } \\
\text { sentence form choices are limited and when semantic and syntactic con- } \\
\text { straints are introduced by a word which has to be included. }\end{array}$ \\
\hline \multirow[b]{2}{*}{ III } & 12 & Processing speech sounds & $\begin{array}{l}\text { Evaluates the ability to discriminate between speech sounds (phonemes) in } \\
\text { minimally different word pairs. }\end{array}$ \\
\hline & 13 & Producing speech sounds & $\begin{array}{l}\text { Evaluates the accuracy in articulating selected elicited speech sounds (pho- } \\
\text { nemes). }\end{array}$ \\
\hline
\end{tabular}

\section{KEY:}

I Language processing subtests

II Language production subtests

IIISupplementary subtests

Appendix B: The list of unfamiliar words with which subjects were familiarized prior to the administration of the Celf

\begin{tabular}{|l|ccc|}
\hline & sneakers & football player & candy \\
\hline & yards & mailman & dollar \\
\hline & drugstore & & \\
\hline
\end{tabular}


Appendix C: Summarized overview of the tests of the Willeford Battery of Central Auditory Function (Willeford, 1974)

\begin{tabular}{|c|c|c|}
\hline & TEST & DESCRIPTION OF EACH TEST \\
\hline \multirow[t]{2}{*}{ I } & Competing sentence test & $\begin{array}{l}\text { The test stimuli consist of simultaneously presented competing sentences presented } \\
\text { to opposite ears. Ten of the competing sentence pairs are presented with the primary } \\
\text { sentence in the left ear and the other } 10 \text { competing sentence pairs are then pre- } \\
\text { sented with the primary sentence in the right ear. The child is asked to repeat the } \\
\text { primary sentence in the test ear. Two percentage scores are then obtained, namely } \\
\text { the weak ear score (test condition: weak ear) and the strong ear score (test condition } \\
\text { istrong ear). The strong ear is usually (but not always) the right ear for young } \\
\text { children. Scores in the weak ear improve until the age of } 10 \text { years when ear perform- } \\
\text { ance becomes equal. }\end{array}$ \\
\hline & Filtered speech test & $\begin{array}{l}\text { The test stimuli consist of low-pass filtered consonant-vowel-consonant words pre- } \\
\text { sented first to the left ear (test condition : left ear) and then to the right ear (test } \\
\text { condition.right ear). The child is asked to repeat the words heard first in the left } \\
\text { ear and then in the right ear. The difference between the left and right ear response } \\
\text { is minimal, i.e. a balanced response is obtained. }\end{array}$ \\
\hline \multirow[t]{2}{*}{ II } & Binaural fusion test & $\begin{array}{l}\text { The test stimuli consist of spondee words filtered in such a way that a low pass } \\
\text { segment is presented to one ear and a high pass segment is presented simultane- } \\
\text { ously to the other ear. The child is asked to repeat the words. The test ear is re- } \\
\text { ported with reference to the ear receiving the low pass segment. The low pass seg- } \\
\text { ment is first presented in the left ear with the high pass segment to the right ear } \\
\text { (test condition : left ear) for the first list of words. The low pass segment is then } \\
\text { presented to the right ear with the high pass segment to the right ear (test condition } \\
\text { iright ear) for the second list of words. The difference between the left and right ear } \\
\text { response is minimal, i.e. a balanced response is obtained. }\end{array}$ \\
\hline & $\begin{array}{l}\text { Rapidly alternating } \\
\text { speech perception test }\end{array}$ & $\begin{array}{l}\text { The test stimuli consist of sentences which are presented in alternating bursts of } \\
300 \mathrm{~m} \text {. sec. duration, first to one ear and then the other. The child is asked to repeat } \\
\text { the sentences. The test ear is the ear in which the first burst starts, for example: } \\
\text { starts in the left ear (test condition. left ear) or starts in right ear (test condition: } \\
\text { rightear). The difference between the left and right ear response is minimal, i.e. a } \\
\text { balanced response is obtained. }\end{array}$ \\
\hline
\end{tabular}

\section{KEY:}

I Cortical procedures

II Brainstem procedures

Appendix D: The list of unfamiliar words and phrases with which the subjects were familiarized prior to the administration of the Willeford Battery of Central Auditory Function

\begin{tabular}{|c|c|c|}
\hline gas & bluejay & sweater \\
\hline Fourth of July & bobwhite & gall \\
\hline band-aid & bonbon & hash \\
\hline baseball & buckwheat & whizzbang \\
\hline football & drugstore & watchword \\
\hline rush hour traffic & soybean & \\
\hline dime & & \\
\hline
\end{tabular}




\section{INFORMATION FOR CONTRIBUTORS}

The South African Journal of Communication Disorders publishes reports and papers concerned with research, and critically evaluative theoretical and philosophical conceptual issues dealing with aspects of human communication and its disorders, service provision, training and policy.

The South African Journal of Communication Disorders will not accept material which has been published elsewhere or that is currently under review by other publications.

\section{MANUSCRIPT STYLE AND REQUIREMENTS}

Manuscripts should be accompanied by a covering letter providing the author's addreas and telephone numbers. All contributions are required to follow strictly, the style specified in the Publication Manual of the American Psychological Assoc. (3rd ed., 1983)(APA Pub. Man.), with complete internal consistency. Four copies of triple-spaced high quality type-written manuscripts with numbered pages, and wide margins should be submitted. They should be accompanied by ONE identical disc copy of the paper. Filenames should include the first author's initials and a clearly identifiable keyword or abbreviation thereof and should be typewritten on the last line of the last page of the Reference List (for retrieval purposea only).

As a rule, contributions should not exceed much more than 30 pages, although longer papers will be accepted if the additional length is warranted. The first page of TWO copies should contain the title of the article, name of author(s), and institutional affiliation (or address). In accordance with the APA Pub. Man. style (1983, p.23) authors are NOT required to provide qualifications. In the remaining two copies, the first page should contain only the title. The second page of all copies, should contain only an abstract (100 words), written in English and Afrikaans. Afrikaane abstracts will be provided for overseas contributors. Major headings where applicable should be in the order of METHOD, RESULTS, DISCUSSION, CONCLUSION, ACKNOWLEDGEMENTS, REFERENCES. All paragraphs should be indented.

TABLES AND FIGURES which should be prepared on separate sheets' (one per page), should be copied for review purposes and only the copies sent initially. Figures, graphs, and line drawings that are used for publication, however, must be originals, in black ink on good quality white paper, but these will not be required until after the author has been notified of the acceptance of the article. Lettering appearing on these should be uniform and professionally done, allowing for a $50 \%$ reduction in printing. On no account should lettering be typewritten on the illustration. Any explanation or legend should appear below it and should not be included in the illustration. The titles of tables, which appear above, and figures, which appear below, should be concise but explanatory. Both should be numbered in Arabic numerals in order of appearance. The number of illustrative materials allowed, will be at the discretion of the Editor (usually about 6).

\section{REFERENCES}

References should be cited in the text by surname of the author and the date, e.g., Van Riper (1971). Where there are more than two authors, after the first occurrence, et al. after the first author will suffice, except for six or more when et al. may be used from the start. The names of all authors should appear in the Reference List, which should be listed in strict alphabetical order in triple spacing at the end of the article. All references should be included in the List, including secondary sources, (APA Pub. Man. 1983, p.13). Only acceptable abbreviations of journals may be used, (Bee DSH ABSTRACTS, October; or The World List of Scientific Periodicals). The number of references should not exceed much more than 30 , unless specifically warranted.

\section{EXAMPLES}

Locke, J.L. (1983). Clinical psychology: The explanation and treatment of speech sound disorders. $J$. Speech Hear. Disord., 48 339-341.

Penrod, J.P. (1985). Speech discrimination testing. In J. Katz (Ed.), Handbook of clinical audiology (3rd ed.). Baltimore: Williams \& Wilkins.

Davis, G.A. \& Wilcox, M.J. (1985). Adult aphasia rehabilitation: Applied pragmatics. San Diego, CA: College-Hill.

\section{EDITING}

Acceptable manuscripts may be returned to the author for revision. Additional minor changes may also be made at this stage, but a note on the manuscript acknowledging each alteration made by the author, is required. The paper is then returned to the editorial committee for final editing for atyle, clarity and consistency.

\section{REVIEWING SYSTEM}

The peer review or refereeing system is employed as a method of quality control of this publication. Peer reviewers are selected by the editor based on their expertise in the field and each article is sent to two independent reviewers to assess the quality of the manuscript's acientific and technical content. The blind peer review system is employed during which the name of the author/ authors are not disclosed to the reviewers. The editor retains the final responsibility for decisions regarding revision, acceptance or rejection of the manuscript.

REPRINTS: 10 reprinte without covers will be provided free of charge.

DEADLINE FOR CONTRIBUTIONS: the preferred date is the 31st May each year, but papers will be accepted until 30th June by arrangement.

QUERIES, CORRESPONDENCE \& MANUSCRIPTS: should be addressed to The Editor, South African Journal of Communication Disorders, South African Speech-Language-Hearing Association, P.O. Box 600, Wits, 2050, South Africa. 


\section{INLIGTING VIR BYDRAERS}

Die Suid-Afrikaanse Tydskrif vir Kommunikasieafwykings publiseer verslae en artikels wat gemoeid is met navorsing, of handel oor krities evaluerende, teoretiese en filosofiese konseptuele kwessies wat oor menslike kommunikasie en kommunikasieafwykings, diensverskaffing, opleiding en beleid gaan.

DieSuid-Afrikaanse Tydskrif vir Kommunikasieafwykings sal nie artikels aanvaar wat reeds elders gepubliseer is, of wat tans deur ander publikasies oorweeg word nie.

\section{MANUSKRIP STYL EN VEREISTES:}

Manuskripte behoort deur'n dekkingsbrief vergesel te word wat die skrywer se adres en telefoonnommers bevat. Daar word van alle bydraers verwag om die styl, soos gespesifiseer is in die "Publication Manual of the American Psychological Assoc. (3rd ed., 1983) (APA Pub. Man."), nougeset te volg met volledige interne ooreenstemming. Manuskripte moet getik, van hoë gehalte en in drievoud spasiëring met wye kantlyne wees. Vier kopieë van die manuskrip moet verskaf word. EEN hiervan moet 'n identiese skyfkopie van die artikel wees. Lêername behoort die eerste skrywer se voorletters en 'n duidelike identifiseerbare sleutelwoord of afkorting daarvan in te sluit en moet op die laaste lyn van die bladsy van die verwsyingslys getik word (slegs vir naslaan doeleindes).

As 'n reël moet bydraes nie 30 bladsye oorskry nie, maar langer artikels sal aanvaar word indien die addisionele lengte dit regverdig. Op die eerste bladsy van TWEE van die afskrifte moet die titel van die artikel, naam van die skrywer(s), en instansie (of adres) verskyn. In ooreenstemming met die "APA Pub. Man." se styl word daar NIE van skrywers verwag om enige kwalifikasies te verskaf nie. Op die eerste bladsy van die twee oorblywende afskrifte moet slegs die titel van die artikel verskaf word. Die tweede bladsy van alle afskrifte moet slegs 'n opsomming ( 100 woorde) in beide Engels en Afrikaans bevat. Afrikaanse opsommings sal vir buitelandse bydraers voorsien word. Hoofopskrifte moet, waar van toepassing, in die volgende volgorde verskaf word: METODE, RESULTATE, BESPREKINGS, GEVOLGTREKKINGS, ERKENNINGS en VERWYSINGS. Alle paragrawe moet ingekeep word.

TABELLE EN FIGURE wat op afsonderlike bladsye (een bladsy per tabel/illustrasie) moet verskyn, moet vir referent-doeleindes gekopieer word en slegs die kopieë moet inisieel verskaf word. Figure, grafieke en lyntekeninge wat vir publikasie gebruik word, moet egter oorspronklike weergawes wees en moet in swart ink op wit papier van 'n hoë gehalte wees. Die oorspronklikes sal slegs verlang word nadat die artikel vir publikasies aanvaar is. Letterwerk wat op bogenoemde verskyn, moet eenvormig wees, professioneel gedoen word en daar moet in gedagte gehou word dat dit leesbaar moet wees na 'n 50\% verkleining in drukwerk. Letterwerk by illustrasies moet onder geen omstandighede getik word nie. Verklarings of legendes moet nie in die illustrasie nie maar daaronder, verskyn. Die opskrifte van tabelle (wat bo-aan verskyn), en die onderskrifte van figure, (wat onderaan verskyn), moet beknop, maar verklarend wees. Numering moet deur middel van Arabiese syfers geskied. Tabelle en figure moet in die volgorde waarin hulle verskyn, genommer word. Die aantal tabelle en illustrasies wat ingesluit word, word deur die Redakteur bepaal (gewoonlik nie meer as 6 nie).

\section{VERWYSINGS}

Verwysings in die teks moet voorsien word van die skrywer se van en die datum, b.v., Van Riper (1971). Wanneer daar egter meer as twee skrywers is, moet daar na die eerste verskaffing van al die outeurs, van et al. gebruik gemaak word. In die geval waar daar egter ses of meer outeurs ter sprake is moet et al. van die begin af gebruik word. Al die name van die skrywers moet in die Verwysingslys verskyn wat aan die einde van die artikel voorkom. Verwysings moet alfabeties in trippel spasiëring gerangskik word. Al die verwysings moet in die Verwysingslys verskyn, insluitende sekondêre bronne, ("APA Pub. Man." 1983, p.13). Slegs aanvaarbare afkortings van tydskrifte se titels mag gebruik word, (sien "DSH ABSTRACTS, October"; of The World List of Scientific 'Periodicals). Die aantal verwysings moet nie meer as 30 oorskry nie, tensy dit geregverdig is.

\section{LET OP DIE VOLGENDE VOORBEELDE:}

Locke, J.L. (1983). Clinical psychology: The explanation and treatment of speech sound disorders. J. Speech Hear. Disord., 48, 339-341.

Penrod, J.P. (1985). Speech discrimination testing. In J. Katz (Ed.), Handbook of clinical audiology (3rd ed.). Baltimore: Williams \& Wilkins.

Davis, G.A. \& Wilcox, M.J. (1985). Adult.aphasia rehabilita* tion: Applied pragmatics. San Diego, CA.: College-Hill.

\section{RESENSERING}

Resensering deur vakkundiges word toegepas as 'n metode van kwaliteitskontrole van hierdie publikasie. Resenseerders word deur die redakteur geselekteer op grond van hulle spesialiskennis en elke artikel word na twee onafhanklike resenseerders gestuur om die kwaliteit van die manuskrip se wetenskaplike en tegniese inhoud te beoordeel. Die naam van die outeur/outeurs word nie aan die resenseerder bekend gemaak nie. Die redakteur behou die verantwoordelikheid vir die finale beslissings aangaande wysigings, aanvaarding of afkeuring van die manuskrip.

\section{REDIGERING}

Manuskripte wat aanvaar is, mag na die skrywer teruggestuur word vir hersiening. Addisionele kleiner veranderinge mag ook op hierdie stadium aangebring word, maar'n nota ter aanduiding van alle veranderinge wat op die manuskrip voorkom, moet verskaf word. Die artikel word dan aan die redaksionele komitee vir finale redigering van styl, duidelikheid en konsekwentheid teruggestuur.

HERDRUKKE: 10 herdrukke sonder omslae sal gratis aan die outeurs verskaf word.

SLUITINGSDATUM VIR BYDRAES: Bydraes word verkieslik teen 31 Mei elke jaar verwag, maar artikels sal nog tot 30 Junie vir aanvaarding oorweeg word.

NAVRAE, KORRESPONDENSIE EN MANUSKRIPTE: moet geadresseer word aan Die Redakteur, Die Suid-Afrikaanse Tydskrif vir Kommunikasieafwykings, Die Suid-Afrikaanse Spraak-Taal-Gehoor Vereniging, Posbus 600, Wits 2050, SuidAfrika. 
